\title{
The Contribution of Monuments to Educating About Holocaust Commemoration in Israel
}

\author{
Ruth Dorot ${ }^{1}$, Shlomit Ben-Ishay ${ }^{2} \&$ Nitza Davidovitch ${ }^{2}$ \\ ${ }^{1}$ Department of Architecture, Ariel University, Ariel, Israel \\ ${ }^{2}$ Department of Education, Ariel University, Ariel, Israel \\ Correspondence: Nitza Davidovitch, Department of Education, Ariel University, Ariel, Israel, Kiriat Hamada 3, \\ Ariel, Israel. E-mail: d.nitza@ariel.ac.il
}

\author{
Received: February 3, $2021 \quad$ Accepted: March 28, $2021 \quad$ Online Published: June 27, 2021 \\ doi:10.5539/ies.v14n7p80 URL: https://doi.org/10.5539/ies.v14n7p80
}

\begin{abstract}
"After the death of the last witnesses the memory of the Holocaust must not be left to historians alone, now is the time for works of art" Aharon Appelfeld.

This study focuses on the role and contribution of monuments to educating about Holocaust commemoration in Israel. Holocaust monuments are located throughout Israel, from north to south, and over the years memorial centers have been added, which contain additional monuments commemorating the story of the specific place and/or personal stories. Many of the latter have original displays from the period of the Holocaust and, according to definitions that will be presented below, these too can be defined as "monuments" and their place as a commemorative site. Commemoration of the Holocaust is an important value in the education of the young generation, as a lesson and as a call to always remember that which happened. The educational system has a very significant role in providing instruction on the memory of the Holocaust and it must teach this complex topic using interesting visual means such as monuments, which have a meaningful role in the story of the Holocaust, similar to journals, letters, films, and drawings. The study explores the role of monuments as meaningful, reliable, and historically valid sources of information, which serve as a visual text for Holocaust instruction. This is with the purpose of examining the meaning of monuments as a source of information in learning about the Holocaust.

The research method: Qualitative research based on observations of a case study consisting of an educational program dealing with remembrance based on monuments and on a catalogue of monuments. The catalogue, built specifically for this study, is unique in its scope and categorizes and charts monuments from different locations throughout Israel, providing a venue for educational activities studying the memory of the Holocaust and its commemoration.

The research findings show that there is at present no organized study program encouraging schoolchildren's visits to monuments in Israel, and these remain abandoned, with no visitors. In many cases they are displayed in open public spaces, and those passing by do not stop to learn their story. Hence, the contribution of the educational program based on the catalogue and on the visit to the monuments will have an effect on all learners, encouraging learning based on experience, i.e., learning outside the classroom. The program blurs the distinction between social classes and sectors and lets each and every student embark on a journey that includes touring, learning, experiencing, and leading.
\end{abstract}

Keywords: monuments, education, Holocaust, commemoration, monument catalogue, anti-Semitism, human identity, innovation, experience

\section{Introduction}

The Holocaust is the most tragic chapter in the history of the Jewish people and of humankind in modern times. The Holocaust of the Jewish people, which led to its systematic, organized, and intentional destruction by a diabolical scheme, the "final solution", occurred during the Second World War, from 1939-1945. From then and to this day we are enjoined to remember and not to forget what happened to the Jewish people in dark times when they were subjected to terrible acts. The obligation to remember is anchored in memory through two dimensions: personal memory and collective memory (Shapira, 1996). The purpose of this study is to examine the contribution of monuments to educating about Holocaust commemoration in Israel. 
The first monuments to the period of the Holocaust consisted of the story - memorial books relating the story of the congregations destroyed. Young claims that every time one picks up a memorial book, he will feel that he is standing by the graves of the victims, because their murderers deprived them even of that (Young, 1996). Memory is an essential and vital component of Jewish survival as a people suffering from persecution. The nation has no goal of revering and sanctifying the dead, but nevertheless it is imperative upon us to remember and we must arouse the public to remember. Memory is a basic concept in Jewish thought, an exigency of a small nation, one that cannot afford to forget. "Collective memory is how society deals with its past, changes its perspective of this past, and kneads it anew to accentuate its uniqueness as a society and to give meaning to its existence" (Gil, 2008, pp. 14-17)

Holocaust monuments shape Israel's memory landscape and give visual expression to a set of messages, meanings, ideas, and ethos's. They cannot commemorate this historical event at its place of occurrence, so they transplant the memory of the event to another selected site for purposes of commemoration. They take part in shaping the collective memory of Israeli society. The power of a monument is measured by its ability to fix historical memory in place (Brutin, 2006). Each visit revives the story of the monument, revives the events for which remembrance is necessary and that led to its construction. In addition, monuments have very important educational value; on one hand they serve as a place for remembering and commemorating the past, and on the other they lead educational values and tasks for the future aimed, among other things, at shaping collective memory and strengthening personal and universal values (Geva, 2017).

Educational programs for Holocaust instruction have a major role in commemorating the Holocaust. An organized educational program that combines various disciplines (history, civics, art, leadership in formal and informal educational settings) and includes educational journeys and tours to monuments within Israel, will transform visits to monuments into a meaningful and important experience for students, as well as enhancing the preservation of memory (Bartal, 2020). Since the reserved design approach of the 1950s, the architecture of commemoration enterprises focusing on the Holocaust has assumed more dramatic lines. Daniel Libeskind's buildings in Berlin and Moshe Safdie at Yad Vashem try to impart to visitors an experience of the inconceivable horror (https://www.globes.co.il/news/article.aspx?did=788949). Israeli architecture as well has covered a long distance from the "Ohel Yizkor" on the top of the Hill at Yad Vashem in the 1950s to the experiential and monumental architecture of recent years (Geva, 2017).

From the 1950s to the 1980s changes are evident in the perception of Holocaust-related memory in Israel. Side by side with the national narrative of Holocaust and bravery, the personal, family angle was added, the project of reading the victims' names was initiated, as well as the discourse on the second generation and journeys by high schoolers to the death camps. A critical discussion began emerging in academia and in the various arts, as well as parallel and competing institutions and museums dedicated to research and commemoration of the Holocaust, from Washington to Berlin. The new design impact of all these led to a spotlight on Israeli monuments and on their role as an experiential source of knowledge regarding memory of the Holocaust (Canetti Yaffe, 2016).

These architectural works center on the concept of user experience. Visiting the structure creates experiences aimed at touching the most terrible (similar to the experiences of high school students travelling to the death camps). The visitor is supposed to contain the emotional experience of the great inconceivable horror (Geva, 2017). Hence, in the current study we explored the role of the monument as a meaningful, reliable, and historically valid source, a source of information that serves as a visual text for Holocaust instruction. This is with the purpose of examining the meaning of monuments as a source of information in learning about the Holocaust.

Canetti Yaffe (2016) notes that the visual representation is at present the main means for commemoration and for acquiring knowledge about the Holocaust. The visual medium began with the publication of photographs and films that exposed the Nazi horror in real time, constituted a foundation for forming Holocaust consciousness underlying commemoration and today, in the era of the internet and social networks, it constitutes the most popular, available, and accessible means for forming public awareness, spreading knowledge, and imparting the memory of the Holocaust. But in a world where the responsibility for conveying knowledge has passed from the professional historian to the visual artist there is also an increased risk of memory obliteration, distortion, and denial that the murder of the Jews by the Nazis and their helpers was an unprecedented act of murder. For example, the Center for the Study of Visual Representations of the Holocaust at Bezalel offers a platform that focuses on examining the different forms of Holocaust-related visual representation, such as drawings, sculpture, cinema, photography, comics, and illustrations that generate a language of signs and symbols, which serve as a foundation for spreading historical knowledge about the Holocaust, constituting as it did an unprecedented act of murder mentioned and commemorated in public discourse in Israel and elsewhere. This is with reference to the frequent changes in how knowledge is accumulated and how consciousness shaped as a consequence of the technological developments 
that directly affect the status of artwork as responsible for spreading historical knowledge (Center for the Study of Visual Representations of the Holocaust).

"Universal history was born in the cities and acquired a central place at the moment of the decisive victory of city over village. According to Marx, one of the great revolutionary bourgeois virtues is the success in "subjecting the village to the authority of the city", with its liberating atmosphere ... The city is the environment of history because it is at the same time both the place in which the social force that facilitates the historical enterprise is concentrated, and the site of past consciousness" (Debord, 2001, p. 175).

The current study deals with the presence of the consciousness of the past in architectural displays in Israel's public sphere, and the significance of the physical monument in shaping a national and individual consciousness of the past. Architecture in general, and monuments in particular, have a crucial role in shaping cultural and national identity as well as in shaping memory and loss of memory. In each period resolutions are reached on the question of which events to commemorate and which to "silence" and obliterate.

This study discusses a case study of monuments commemorating the Holocaust in Israel as examples of how the consciousness of the past is shaped in the public domain. The force of these monuments is contained in the dialectic presence they give to the memory of the past - past and present, past and future, particular and universal, objective and subjective, and victim and aggressor. These works manage, in different ways, to "grasp" the dialectic tension and thus evade the danger of banalization and in fact the obliteration of memory concerning the past (Canetti Yaffe, 2016).

The current work will focus on the role and contribution of monuments in educating about the memory of the Holocaust and its commemoration in Israel. Holocaust memorial monuments are spread, as stated, throughout Israel from north to south. Over the years memorial centers were added, and they include monuments that commemorate the story of the place and/or people. Many of them include original displays from the period of the Holocaust and, according to definitions that will be presented in the paper, these too can be defined as "monuments" and the place as a commemorative site. Commemorating the Holocaust is an important value in the education of the young generation, as a lesson and as an injunction to remember that which happened for all time. The role of the educational system in teaching the memory of the Holocaust is very significant and it must educate about this complex subject through varied means such as monuments that have a significant role in the story of the Holocaust, for instance diaries, letters, films, and drawings. Monuments bear a commemoration format that is part of the plastic arts and they serve as a visual source for learning; they are original and interesting, their size is large and impressive, they are suitable for use as an educational tool for teaching the Holocaust to all ages because seeing for oneself is best and "one picture is better than a thousand words".

\section{Holocaust and Human Identity}

The Holocaust of the Jewish people in the Second World War is a traumatic and constitutive event in human history in general and in the history of the Jewish people in particular. The Holocaust has become a major component in the national identity consciousness of Jews in Israel and in the Diaspora. It is a major link in the Israeli experience and an essential component in shaping Jewish-Israeli collective identity (State Comptroller's report, 2010). In 2009, for about two months, the State Comptroller examined how the Holocaust is taught and how its lessons are imparted within the educational system. The pedagogical instructions and actions of the Ministry of Education and the obligatory framework for teaching the Holocaust in each sector by discipline and by age group were examined, as well as the application of various recommendations provided by the Ministry of Education, such as those of the Shenhar Committee (1991) (Note 1) and the Shenhar program's mutual relations with institutions for commemoration of the Holocaust.

The program "In the Paths of Memory" was published by the Ministry of Education and Yad Vashem in 2013-2014 under R. Shay Piron as Minister of Education. A first of its kind, it is the most recent in a list of ministry programs for teaching about the Holocaust. This new program, unlike its predecessors, obligates instruction of the Holocaust at all ages. The rationale of the program says that according to the school program for teaching the Holocaust, consciousness of this subject has become an inseparable part of Jewish, Israeli, and human identity. Students in Israel, as part of Israeli society, hear about the topic of the Holocaust from a young age and throughout adolescence. Addressing this complex subject at school helps students process the contents. The educational system teaches children about the heritage of the people, the history, and the culture. (Note 2)

According to Aba Kovner the Jewish Hebrew and Yiddish poet, writer and partisan leader, we must reach the recognition, as long as it is not too late, that the Holocaust is not the obsession of those who remained and that communing with the six million victims and learning the lessons of that period are not merely a matter for those who experienced the horrors firsthand, rather part of the Jewish people's lengthy collective memory, and the 
Holocaust has a place in the historical consciousness of all Jewish generations (Kovner, 1998).

Versus the significance of remembrance and commemoration as part of formulating Jewish-Israeli identity, there were also those who objected, a limited number of voices claiming that the Holocaust must be forgotten and Israel must look to the future and erase its past as part of building an equitable democracy for all its citizens and inhabitants. Elkana (1988) wrote in his jarring article "In support of forgetting" (Note 3) that there is no greater danger to the future of Israel than the fact that the Holocaust has been systematically and forcefully inserted into the consciousness of the entire Israeli population, even those who did not experience the Holocaust, as well as to the next generation born and raised here (Elkana, 1988).

\section{Monuments Are Memorial Installations}

Monuments commemorate that which is not present - the existent commemorates the vacuum or the nonexistent. Monuments can be called "realms of memory". French historian Pierre Nora described the process of forming "realms of memory". Nora determines two stages: The first is the transition from the occurrences themselves and knowledge of them in a certain society. The second is the transition to recording these events as history. The first stage he calls "environment of living memory". In this state there is not yet a need for a means of remembering, as the events are fresh and alive in consciousness. The second stage is one in which "realms of memory" are established - institutions, memorial books, monuments, etc. This need results from the risk of forgetting (Nora, 1993).

As stated, monuments have considerable value for affixing historical memory, which is enhanced by each visit that revives the story of the monument, reviving the events for which remembrance is necessary and that led to their construction. In addition, monuments have very significant educational value; on one hand they serve as a place for commemorating the past, and on the other they advance educational values and missions for the future aimed, among other things, at shaping collective memory and strengthening personal and universal values. These are inanimate lumps of stone, but each of them has at its foundation unparalleled acts of bravery, sacrifice, friendship. These acts of bravery should be the focus of education (from the words of Ariel Sharon when inaugurating the "Black Arrow" monument (Sharon, 2003)).

Each monument tells a story determined by those who erected it, in addition to the story of its establishment and integration in the existing memory fabric. In order to understand the monument, several simple questions are necessary: What is the story that it aims to relate, how is it supposed to relate it, who wanted to tell the story and to whom, and after it is erected - how does it function in the overall ceremonial and symbolic life of the community that is supposed to remember? There is a meaningful association between two communities - the commemorating community and the remembering community. It is necessary to explore whether the association exists today - the interaction between the two communities will dictate the meaning of the monument within the collective memory fabric. While the first is charged with serving as a community that commemorates its story and tells its story by creating the site's meaning, the role of the second community is to utilize and confirm the meanings of the remembrance (Shamir, 1996).

The definition of "Holocaust commemoration" depends on the form and place. The national memory of that called the "Holocaust" changes between countries and between regimes. Each site should be allowed to offer a definition of its own, guided by its place and by the content it wishes to advance and promote (Dorot, 2015, p. 298). Young claims that it is necessary to sanctify the never-ending argument in the endlessly changing conditions about the type of memory that should be preserved, instead of determining a single form of monument that will serve as the chosen form of memory. Monuments tend to actualize only a small number of historical affairs. They present themselves as a natural growth, a type of geological formation within the national scenery. In time, this legendary memory becomes a natural site, similar to the scenery within which it is located (Young, 1996), and the moment it is assimilated within the surrounding scenery what remains of its role?

Some artists and sculptors say that the possibility of reducing the memory of such grave events to displays of public art or of cheap pathos is insufferable. They completely reject the traditional forms and the customary justifications of public commemorative art, those sites that seek to console the audience or to grant atonement for such tragic events or those that pretend to heal the memory of a nation that was obliterated. These artists are concerned that instead of engraving the memory in public consciousness, customary monuments seal the memory and separate it completely from public consciousness. They are concerned, and rightly so, that when we encourage monuments to perform the work of remembering in our stead, we ourselves become more forgetful (Young, 1996).

The first "memorial monuments" for the period of the Holocaust were made not of stone, glass, or steel, but rather of stories - memorial books. These books told the story of the Jewish communities in Europe that were 
destroyed during the war by the evildoers. Indeed, one of the books says in its introduction: "Every time we pick up the book, we will feel that we are standing by the graves of the victims, because the murderers deprived them even of that" (Young, 1996, p. 599). Memorial books were the first "abstract" monuments through which authors recording the Jewish communities attempted to commemorate the memory of the congregation and of the people, hoping that by reading them they would become commemorative sites and memorial spaces.

Monuments are dependent on the people who visit them and, on the stories, they create, otherwise they will remain silent stones that blend in with their surroundings and do not fulfill their original role but, on the contrary, encourage forgetfulness. Ruth Dorot, in her article "From the poetic to the political", defines monuments as select artwork and educational activities in Israel and abroad that constitute a representative collection on the topic of Holocaust commemoration, aimed at educating future generations. When endeavoring to explore the significance of monuments it is necessary to examine their impact on the feelings of their visitors, their location and accessibility to the public, and whether all these achieve the main goal, which is relating the story of the Holocaust, commemorating it, and passing it on as a warning sign (Dorot, 2015).

"We build monuments to remember, and we build memorial sites to avoid forgetting", said Arthur Danto, art critic and philosopher. This definition was expanded by James Young, who himself relates to all memorial sites as commemorative sites and to their contents as monuments - "A commemorative site can be a day, a convention, a space, but it is not necessarily only a monument; in contrast, all monuments are commemorative sites" (Dorot, 2015, p. 300).

Young (2015, p. 300) claims that every monument is always a commemorative site, hence it may be deduced that every memorial center for the victims of the Holocaust is a commemorative site and its displays are monuments. Collections of displays from the Holocaust period will be transformed into authentic monuments by virtue of the memorial story they commemorate, and due to their documentary value, they will become a foundation for extensive educational work that will be built around them and based on their story. A monument can be defined as a stone installation in an open space, or an authentic display presented in a memorial center, so long as it represents the period of the Holocaust, describes what happened, and tells a personal, family, or communal story. Visiting it will arouse feelings based on the experience, with exposure, learning, and internalizing that take place throughout the year, unrelated to the memorial days determined by law, and will leave a long-lasting impression on the student.

When mapping the commemoration enterprises in Israel we encounter a large array and mixture of such enterprises. Some were founded by people privately, in memory of their family, while others are public and were erected by the government, local authorities, kibbutzim, organizations, schools, donors, and others.

\section{The Purpose of the Study and Its Innovation}

The purpose of the study was to explore the contribution of monuments to remembrance and commemoration of the Holocaust in Israel's educational program for remembrance of the Holocaust. Monuments shape Israel's memory landscape. They exist throughout the country, in cities, kibbutzim, parks, and forests. Some are included within memorial centers and others are in the open public space. They are accessible to all and constitute grounds for learning and for expanding knowledge with regard to the story of the person, community, and place that they commemorate. They have important educational value and visiting them enlivens the story they tell as a visual text that demonstrates and illustrates a historical-tragic event that is distant from the visitors in time and place. Therefore, educational activities must be held around them on a level that will grant the visit educational value.

The study will examine the role of monuments as a meaningful, reliable, and historically valid source of information, one that will serve as a visual text for teaching about the Holocaust. These monuments should serve as "road signs" in the future educational journey of students in Israel's educational system. The study characterizes monuments for Holocaust remembrance through an extensive representative catalogue constructed for this study, which included forming a cross-section of monuments by topic, such as monuments in public and private spaces, in cities or in nature, in JNF forests, and more. In addition, the catalogue provides a classification by type of monument (isolated monument and/or installation within a memorial complex), location, initiators of the monument, event story, educational projects, and journeys. The catalogue, which maps Israel's monuments by topic, is original and illuminates the various areas in which students will receive added value along the memorial journey.

In this study we shall discuss the role of monuments and their contribution to education for Holocaust remembrance. Monuments tell a story, whether personal or collective, and are formed as seen by the artists who seek to convey their story. Through the monument, observers are exposed to the deep emotional experience that 
the artist chose to share, and this story will be transformed into an educational act - an educational program (Note 4) for commemorating the memory of the Holocaust - "Monument-Based Remembrance". The structure of the program specifies the educational rationale and the main principles of the program devised for this journey. The journey will include visits to monuments throughout Israel as well as to memorial centers that portray unique and special displays commemorating the Holocaust, defined as monuments by virtue of the educational activities held around them. The "Monument-Based Remembrance" journey and the accompanying intervention program are very significant. First and foremost, familiarity and exposure of monuments to high school students as a source of information for learning about the Holocaust. The monuments will expand their knowledge about this period. Each will tell a different story and will portray an additional aspect regarding the period of the Holocaust. Moreover, in the process of learning the students will be trained as counselors in order to encourage their practical and volunteer work as well as to develop their sense of self-efficacy, and they will guide their peers on the journey. Training them to be young counselors will instill in the student's meaningful values of giving, patience, and tolerance of others, leadership, partnership, respect for the historical past, and the need to convey the "story" of the Holocaust further, so that it will not be forgotten.

\section{Research Method}

For the purpose of the study a monument catalogue was written by the authors of this research, which categorizes Israel's Holocaust memorial monuments. The catalogue includes Holocaust memorial monuments throughout the country, as well as Holocaust memorial centers that portray authentic, unique, and meaningful items, in which extensive educational activities are held for commemoration purposes. In addition, the catalogue presents educational programs operated following visits to familiar official monuments and those that became monuments following the educational activities held in them. Charting the monuments and their categorization in different domains presents a wide range of commemoration sites spread throughout the country, from which were selected sites from different geographical areas, varied in size, form, and material, but each tells a visual testimonial story, the story of individuals, a family, and a community; all tell a story of bravery and some also of revival.

\section{Research Hypotheses}

Monuments belong to a form of commemoration that is part of visual plastic arts, therefore:

a) Holocaust memorial monuments in Israel will be found to contribute to Holocaust remembrance and to serve as a visual educational bridge for learning about the Holocaust.

- Educational-pedagogic aspect - Monuments will be found to serve as a significant updated source of information for knowledge about the historical event they present, within all the era's general historical events.

- Value-related aspect - Monuments will be found to serve as a source for meaningful teaching of universal and personal values.

- Rational/cognitive aspect - Monuments will be found to serve as a source for developing abstract thinking processes that enable understanding meaningful occurrences in the Holocaust.

b) An association will be found between the contribution of monuments in the cognitive and value-related aspect and students' profile (personal background, family background - ethnicity, place of residence, religion, third/fourth generation, academic state).

c) An association will be found between the educator's role as knowledge agent of the monument's content story as a visual-artistic-experiential historical text, and its meaningfulness for Holocaust instruction.

d) Tours of monuments will be found to constitute the basis for the study program teaching Holocaust remembrance.

e) The study program for all students, whether they participated in the journey or not, will lead to equality among the students with regard to learning about and the need for Holocaust commemoration.

Monuments are an artistic display used for educational activities within the process of teaching Holocaust remembrance to the next generations.

Displays at Holocaust remembrance centers, used for Holocaust instruction in three aspects - educational, cognitive, and value-related - will be defined as monuments by virtue of being artistic displays. and educational commemoration activities centering on them will be held; therefore, they will be found to be a significant and 
influential part of the educational process.

The working premise of the study is that a study program based on visiting monuments will expand historical knowledge about occurrences in the Holocaust, as well as telling the story of the artwork and of the artist in connection with the Holocaust. On one hand, monuments do not describe an event in the "here and now", they were not constructed neither in the time nor at the place of the events, but their time of construction and placement were selected pedantically by their creators and hence their connection to the Holocaust and in some cases also to the revival. The educational procedure that will accompany the visit to the monument will change the visit from one that lacks meaning and purpose to a meaningful visit for the learners. Aside from the historical knowledge acquired by the student, the added value of imparting personal and universal values will be explored, first and foremost the value of commemorating and imparting Holocaust remembrance, values of human dignity, the sanctity of life, values of family and tradition, equality, patience and tolerance, caring for others, and self-realization. The third aspect we shall investigate, the cognitive aspect, is developing high-order thinking skills of conceptualization, justification, all the behavioral-mental divisions whose basic features are abstract in essence and that incorporate symbolization, insight, observation, complex use of rules, concentration, and problem solving.

\section{Qualitative Research}

The rationale and concept of the program-monument catalogue:

In order to construct this educational program, we conducted extensive research and established a thorough and variegated catalogue of monuments in Israel. The catalogue is built and divided by topic and describes the different types in the various parts of the country. This catalogue is unique in its scope, variety of areas, communities, types, artists, and historical stories that it presents and represents. The program is aimed at increasing students' awareness of various types of commemoration, with the aim of encouraging learning by means of a memorial installation that is less accessible and familiar to the students. The program is based on the three principles of meaningful learning (Ministry of Education, 2014):

- Value for the student and for society - Meaningful learning is perceived as having essential value for people and for society, where students learn and implement skills that promote practice and achievements for themselves in particular and for society in general.

- Involvement of the student - In the program students receive the opportunity to be active partners in the learning process, by suggesting initiatives and carrying out learning processes, choosing ways of learning in a team, presenting products, providing and receiving feedback.

- Relevance for learners - Meaningful learning invites dealing with challenging, intriguing, interesting ideas, contents, and messages adapted to the learners. It links previous knowledge to new knowledge needed by students as individuals and as part of society.

Meaningful learning is also possible in a digital environment, in encounters with various information sources, and when developing skills and ways of thinking characteristic of life in a technological society. In addition to the technological innovations, students will be able to experience an environment that combines art and photography (Note 5), such that other student skills will also be manifested during the program.

The following are the themes revealed, explored, and presented in the monument catalogue.

Sample-based mapping of monuments in Israel - from the monument catalogue:

It is possible to encounter three types of monuments. The first invites the observer to stand facing it. The observer enters the monument plaza or space and stands facing the sculpted element that usually bears writing, which gives information about the event commemorated by the monument. The second type is a monument where the sculpted element and writing are in the center and the plaza surrounds it. The observer walks around the monument and is exposed to it in its entirety. The third and final monument is one that includes a commemoration space which has an exterior and interior, but only when entering does the visitor sense its intensity (Brutin, 2005). Each type of monument creates a different interaction with the visitor, manifested in the intensity of the emotional, cognitive, and physical experience and affecting the visitor's learning process.

In the monument catalogue, written for the study and intervention program, representative and unique memorial sites were chosen that fit the definition of 'monuments' as commemorative sites. Educational activities on remembrance of the Holocaust are held at the sites or, alternately, the place is recommended as a site where educational activity may and should be held, as recommended in the intervention program.

Examples of private and municipal commemoration enterprises: 
"Joseph Bau House" - Visitors are exposed to a fascinating and moving life story of rescuing Jews in the Holocaust and in Israel, of seeing the positive in life and learning how humor, love, and optimism help people survive even in extremely difficult life situations.

"Streets witness" - Excursion program for students on a "bravery route" established in Petach Tikva. The route passes through streets named after Jewish heroes from the Holocaust period.

Monuments erected by founders of a kibbutz in memory of their family members murdered in the Holocaust

Holocaust monument, Kibbutz Ginosar - This monument was erected by members of the kibbutz) the traditional kibbutz is a community that lives together and engages in agriculture) who came to the country before the war broke out and lost their entire family. Through the monument they sought to commemorate their relatives who had been killed in the Holocaust.

Monuments in an urban landscape - reflecting revival and a description of how life continued after the horrors

Holocaust and revival monument - Tel Aviv, Rabin Square. Sculptor: Igael Tumarkin. "The monument distinctly symbolizes the Holocaust and the revival. "I wished to express a terrible physical distress that is relieved and that bursts out as happiness" (Tumarkin, 1973).

Monument to Victims of the Holocaust - Weizmann Institute. A memorial monument on which are engraved Hebrew names, as the prisoners' numbers were tattooed on their arms in Auschwitz. From the words of Chaim Weizmann at a eulogy he gave at the Zionist Congress in 1946 - engraved on the monument: "Remember... There is almost no one among us - here and in the Land of Israel where Jews live - who has lost no family members. Thousands of links tie us to the holy and pure ones who were butchered. One day they will be written in the book of history, and there will be a judge who will weigh the deeds of humanity with just scales" (Weizmann, 1946).

Monuments in public parks for general use

"The weeping harp" - Kiryat Gat.

"In memory of the Jewish fighters against the Nazi enemy" - in memory of those who fought against the Nazis and their allies - Rishon Lezion.

\section{Monuments in memory of events/congregations}

Monument in memory of the deportation of French Jews - the Ella Valley, Beit Shemesh. A memorial wall dedicated to the 80,000 victims of the Final Solution of the Jewish problem in France. Around the monument 80,000 trees were planted in memory of the victims. The site was erected by the Sons and Daughters of Jewish Deportees from France, in the feeling that not enough had been done in France to commemorate the mass deportations. (Note 6)

Monuments commemorating people who fought for their community.

The Eliezer Geller memorial for the Warsaw Ghetto fighters - Kibbutz Maale Hahamisha. Monument for the Warsaw Ghetto fighters - representation of bravery. Kibbutz Maale Hahamisha was established in 1938 by members of the Gordonia movement in Poland, a Zionist-pioneering youth movement that espoused the values of A.D. Gordon. After the war, members of the movement who had survived the Holocaust joined the kibbutz. Eliezer Geller, a member of the Gordonia movement, was one of the leaders of the uprising. The kibbutz members wished to commemorate his memory and that of members of the movement by erecting this monument.

Monument in memory of Mordechai Anielewicz - Kibbutz Yad Mordechai. The first monument erected in Israel to commemorate the bravery of the Warsaw Ghetto fighters. Named for the leader of the uprising, Mordechai Anielewicz. The kibbutz was founded by members of the Hashomer Hatza'ir movement in Poland. Sculptor Nathan Rapoport linked the fighting in the Warsaw Ghetto to kibbutz members who fought against Egypt in the War of Independence.

Monuments in memory of the children murdered in the Holocaust.

Kibbutz Mishmar Ha'emek - A monument that serves the kibbutz members to this day as a place of remembrance and of communion with their relatives murdered in the Holocaust. It was the first to be erected in memory of the children murdered in the Holocaust even before Israel was founded, by sculptor Ze'ev Ben Zvi in 1947.

Monument in memory of the million and a half children murdered in the Holocaust. Beit Lohamei Hagetaot This monument is unique for its preliminary design and planning, which emphasized that the place should 
become an educational center and facilitate activities for children and youth.

\section{KKL-JNF forests}

Forests in commemoration of victims of the Holocaust - Defenders' forest, the Polish Jewry site, forest in memory of the congregation of Zaglambia - Forests in the Jerusalem Hills area. The forests are a symbol of freedom and survival for those Jews who managed to flee the ghetto and join the partisans. KKL-JNF created a combination of commemorating the bravery and remembrance of different Jewish congregations in the heart of the forests, and most are concentrated in the area of the Jerusalem Hills.

\section{Conclusion and Discussion}

As mentioned above, this paper sought to describe the construction of a catalogue that charts the effect of monuments aimed at preserving the memory of the Holocaust in Israel's public sphere. In contemporary western culture, completely controlled as it is by visual images that are almost all produced and utilized in urban spaces, the significance of memorial and commemoration sites for shaping worldviews, including shaping national consciousness of the past, should not be underestimated. Monuments are a type of documentation that is complex, continuous and non-continuous, purposeful and accidental, heterogenous, planned but also with contingent phases, stable but with a very strong transient dimension. This complex entity that comes into being in space and time, reflects a consciousness of the past.

Monuments and memorial sites in Israel's public sphere may serve the narrative of historical continuity better than museums that are not necessarily visited, and than research institutes that are not accessible to the general public, not only in the diachronous sense of the sequence of responsibility and blame but also in the synchronous sense where the physical expanse does not allow us to "put the past behind us" and insists on living in the present. Holocaust monuments and stumbling stones undermine the tradition of the monuments as they do not aim to preserve the memory of the past as an outstanding objective past event, rather their aesthetic and spatial strategies require active participation in the urban space that is preserved as a diachronous continuum and as a synchronous fabric of events in the past and present. These monuments are characterized by an interpretive and experiential dynamism, resulting from how the observer, the visitor, participates actively in the event. In this way, entrapment in false representations is avoided.

The current research findings show that monuments have the potential of commemorating the Holocaust and educating about Holocaust remembrance in Israel and elsewhere. Monuments shape the memory landscape in Israel; they are spread throughout cities, kibbutzim, parks, and forests. Some are in memorial centers and others in the open public space. They are accessible to all and constitute a fnddat for learning and for expanding knowledge about the story of the person, community, and place that they commemorate. They have important educational value; visiting them enlivens the story they tell as a visual text and therefore it is necessary to hold educational activities around them such that the visit will acquire educational value. The study examined the role of the monument as a meaningful, reliable, and historically valid source, a source of information that serves as a visual text for Holocaust instruction.

The study characterizes Holocaust remembrance monuments through an extensive catalogue that includes a cross-section of monuments by different topics - type of monument (single monument and/or display within a memorial complex), location, constructors of the monument, story of the event, journeys, and educational projects. The "monument-based remembrance" journey is very significant for familiarization and exposure of teens to the monuments and for understanding their meaning as a source of information when learning about the Holocaust. The monument will expand their knowledge about this period; each monument will tell a different story and present another or an additional aspect with regard to the Holocaust. The monuments incorporate the potential of experiential learning, as well as of teaching meaningful values of giving, patience, and tolerance of others, leadership, partnership, respect for the historical past, and the need to convey the "story" of the Holocaust so that it will not be forgotten. The monuments invite activities that comprise active educational and experiential learning of the topic, not only on memorial days. Thanks to them, exposure to the topic of the Holocaust is increasing, as every visit to such a place accentuates the significance of the topic, imparts values, and enriches with knowledge that does not necessarily exist in the textbooks.

The State Comptroller's report, published in 2010, presents a concerning state of affairs regarding Holocaust studies in Israel's educational system. Many studies have dealt with ways and methods of teaching the young generation this important chapter in the history of the Jewish people. Many addressed the question of who is responsible for educating about Holocaust remembrance and what is the added value of learning about this topic for students. Alongside those advocating systematic instruction of the topic of the Holocaust there are others who object, claiming that the past should be left in the past so that we can proceed towards a better future. The Yad 
Vashem Holocaust Martyrs' and Heroes' Remembrance Authority, as well as many museums established upon the founding of the state and until the present, develop adapted and accessible teaching programs for the different ages while providing support and guidance for the teaching staff who are not always experienced in teaching this area, in order to form a well-established and strong foundation for learning and teaching the subject. After the State Comptroller's report was published, the "In the Paths of Memory" program became a mandatory program in the schools, and it includes lesson plans and continuing education for teachers.

The "Monument-Based Remembrance" study program for commemoration of the Holocaust is accessible to everyone and it encourages experiential learning, i.e., learning outside the classroom. The program affords an equal experience to students from different social classes and sectors and lets every student go on a journey in which they will tour, learn, experience, be taught, and lead. In the definition of the monuments, memorial centers should be defined as commemorative sites and their displays as monuments - so long as active, educational, and experiential learning of the topic takes place around them, not necessarily on memorial days. This definition expands the places that can be included in the journey, making it possible to increase exposure to the topic of the Holocaust, as every visit to such a place enhances the significance of the topic, imparts values, and adds knowledge that does not necessarily appear in the textbooks.

Today, anti-Semitic winds are once again raging in the world. We are witnessing many cases of life-endangering verbal and physical injuries, with the height of these being cases of real terrorism and murder perpetrated against Jewish communities and individuals around the world. We must be concerned about the loss of shame with regard to anti-Semitism. When the first photographs from Auschwitz appeared at the end of the Second World War, the western world was ashamed at the results of the blatant anti-Semitism. Anti-Semitism indeed did not disappear consequently, but this sense of shame served for several decades as a restraining element with regard to public displays of anti-Semitism. Carole Nuriel, Director of the Anti-Defamation League's Israel Office, said so in an article published for International Holocaust Day (Muriel, 2018). Education is one of the major tools for fighting anti-Semitism - educating for democracy, equality, and human love, as well as educating for commemoration and remembrance so that we will remember that which happened in order to create a safe future devoid of hatred.

\section{References}

Bartal, I. (2020). Status report on Holocaust studies at research universities and colleges in Israel, 2020. Israel Academy of Sciences and Humanities, Jerusalem. Retrieved from https://www.academy.ac.il/Index3/Entry.aspx?nodeId=769\&entryId=21078

Brutin, B. (2005). Living with Memory - Holocaust Memorial Monuments in Israel. Beit Lohamei Hagetaot.

Canetti Yaffe, Y. (2016). Shaping the consciousness of the past in the public space: A dialectic of Holocaust remembrance in Berlin (pp. 28-43). Architext. Ariel University, Ariel.

Davidovitch, N., \& Soen, D. (2011). Teaching civics and instilling democratic values in Israeli high school students - The duality of national and universal aspects. In N. Davidovitch, \& D. Soen (Eds.), Holocaust Remembrance - Issues and Challenges (pp. 178-192). Ariel University Center of Samaria.

Debord, G. (2001). The society of the spectacle, thesis 176. Translated by D. Raz. Bavel Publishing.

Dorot, R. (2015). Between the political and the poetic: Holocaust monuments. In N. Davidovitch, \& D. Soen (Eds.), The Valley of the Shadow of Death: The Holocaust Experience from a Multidisciplinary Perspective (pp. 295-340). Ariel University of Samaria: Resling. [in Hebrew]

Elkana, Y. (1988, March 2). In support of forgetting. Position paper. Ha'aretz. Retrieved from https://www.haaretz.co.il/opinions/1.1841380

Geva, S. (2017). The Shoah - an educational lesson. Tel Aviv: Hakibbutz Hameuchad.

Gil, A. (2008). The changing representation of the Holocaust in Israeli collective memory. Adkan, 47, 14-17.

Knesset of Israel. (1953). Debate in the Knesset on the Holocaust and Bravery Remembrance Law - Yad Vashem, 1953. Annals of the Knesset, Vol. XIV (pp. 1209-2402).

Knesset of Israel. (1953, May 12). Debate in the Knesset on the Holocaust and Bravery Remembrance Law Yad Vashem, 1953. Annals of the Knesset, Vol. XIV (pp. 1310-1314).

Knesset of Israel. (1953, May 18). Debate in the Knesset on the Holocaust and Bravery Remembrance Law Yad Vashem, 1953. Annals of the Knesset, Vol. XIV (pp. 1331-1353).

Kovner, A. (1988). In R. Korczak-Marla \& Y. Tuvin (Eds.), Abba Kovner: Seventy Years (p. 44). Tel Aviv: 
Moreshet and Sifriat Poalim.

Kovner, A. (1998). Delaying the Tearing. Am Oved.

Nora, P. (1993). Between history and memory: The problem of the place. Zemanim, 45, 4-19.

Nuriel, C. (2018). Anti-semitism in Today's World-Still a Cause for Concern. Retrieved from https:/www.ynet.co.il/articles/0,7340,L-5075094,00.html

Shapira, A. (1996). The Shoah: Individual memory and public memory. Zemanim, 57, 13-14.

State Comptroller's report. (2010). Instruction of the Holocaust and Imparting its Lessons in the Educational System (Annual report 60b).

Tel Aviv-Jaffa Municipality. (1973, April 4). Tumarkin's Explanation of the Monument. Municipality spokesperson's announcement. Municipal Archives.

The Israeli National Academy of Sciences. (2020). Status report on Holocaust studies at research universities and colleges in Israel.

Young, J. E. (1987). From remembrance to monument. Masuah, 15, 137.

Young, J. E. (1994). The Art of Memory - Holocaust Memorials in History. James E. Young (Ed.). Germany: Prestel.

Young, J. E. (1996). Germany's disappearing memorials. In I. Gutman (Ed.), Major Changes within the Jewish People in the Wake of the Holocaust (pp. 595-602). Jerusalem: Yad Vashem.

\section{Notes}

Note 1. The Shenhar Committee was established by the Minister of Education, the late Zevulun Hammer, in 1991. The Chair of the committee was Prof. Aliza Shenhar, Rector of Haifa University. The purpose of the committee was to examine the state of Jewish studies in the secular state school system. The committee recommended, among other things, learning about the place of anti-Semitism in the modern world, the meaning and lessons of the Holocaust, and ensuring that the period of the Holocaust would continue to be a central topic in the teaching program in schools and in the community. The committee's recommendations were almost completely disregarded on all age levels.

Note 2. In the Paths of Memory - Educational program for teaching the Holocaust in elementary and high schools. Developed in collaboration by the Yad Vashem International School for Holocaust Studies and the Ministry of Education.

Note 3. Yehuda Elkana, a Holocaust survivor, was an Israeli intellectual, a professor of scientific history, and an educational activist. He was a sharp critic of Israel's educational and pedagogical methods both in the instruction of science and in the instruction of the Holocaust and instilling the memory of the Holocaust in Israel.

Note 4. The "Monument-Based Remembrance" intervention program is presented in the appendices chapter of this study, pages 36-43.

Note 5. Student workshops - intervention program, pages 36-43 in the 'Appendices' chapter.

Note 6. The educational value of commemorating the Holocaust is enhanced by visiting this monument. The students are less familiar with the story of French Jewry. They learn mainly about the Holocaust of Polish Jewry, among other things as a result of the journeys to Poland. Visiting monuments that tell the story of additional communities is meaningful for expanding students' historical knowledge while also reinforcing the value of commemoration and remembrance.

\section{Copyrights}

Copyright for this article is retained by the author(s), with first publication rights granted to the journal.

This is an open-access article distributed under the terms and conditions of the Creative Commons Attribution license (http://creativecommons.org/licenses/by/4.0/). 